Webology, Volume 17, Number 1, June, 2020

\begin{tabular}{|l|l|l|l|}
\hline Home & Table of Contents & Titles \& Subject Index & Authors Index \\
\hline
\end{tabular}

\title{
Effect of Continuous Improvement of Information Technology Applications on E-Costumer Behavior in Social Media
}

\begin{abstract}
Anaam Abdulzahra Meteab
Professor, Faculty of Administration and Economics, University of Kufa, Iraq. ORCID: 0000-0002-7037-8485. E-mail: anaama.meteb@uokufa.edu.iq
\end{abstract}

\section{Arcelan S. Sadiq}

Assistant lecturer, Foundation of Technical Education, Iraq. ORCID: 0000-0002-0808-8073. E-mail: arcelans@yahoo.co.uk

\section{Hamad Karem Hadrawi*}

*Corresponding Author, Professor, Faculty of Administration and Economics, University of Kufa, Najaf, Iraq. ORCID: 0000-0003-0877-1566. E-mail: hamadk.hadrawi@uokufa.edu.iq

Received January 15, 2020; Accepted June 20, 2020

\section{Abstract}

A continual improvement process is an ongoing effort to improve products, services, or processes. Delivery processes are evaluated and improved through continual customer evaluation in the light of efficiency and effectiveness, especially for e-customers active on social media. For this and much more, studies highlight the importance of adopting technological applications to improve business and influence customer behavior. This study also investigates the effect of continuous improvement of information technology applications on e-customer behavior; the results of the experimental study are based on the samples of the social media users in Iraq. The model was tested through structural modeling method, and the results proved that technological applications should be adopted to influence e-customer behavior.

\section{Keywords}

Information Access; Applications; Automation; Employment opportunities 


\section{Introduction}

Customer behavior is affected by varied factors. Several studies have tried to find out the factors that affect customer behavior (Juaneda et al., 2016). Previous studies have highlighted psychological factors, economic factors, cultural factors, and personal factors as the main influencers of customer behavior (Jose, 2017). But in the recent past, the market has undergone a major shift in customer behavior as it has become more complex and this complexity, however, can be associated more with the advancement in technology. Understanding customer behavior is a key to success, therefore studying the customer behavior and meeting their preferences and needs is essential. According to (Söderlund, 2018), customer behavior entails the act of studying how individual customers, organizations, groups or institutions buy, select, use or even dispose of ideas, goods, and services to satisfy their needs. Newman et al. (2013) say that in a nutshell, customer behavior is simply the act of sitting back and studying the actions of customers in the marketplace to come up with goods and services that matches their preferences, which in other words means the act of satisfying the customers. Companies adopt this to retain a large market share. Customer behavior is divided into complex, habitual, dissonance reducing and the varietyseeking buying behavior (Yi \& Taeshik, 2013).

Unlimited access to information and simplification of processes have empowered the user with decision-making and the ability to leap from one company to another (Jankowski, 2009). Not surprisingly, the internet has opened a door to a myriad of products and offers that can be accessed from the comfort of their homes, which has exponentially increased the competition for the companies. "The digital transformation has made it easier for customers to the switch from one company to another. The client is no longer loyal to one brand, which creates pressure on organizations to make the experience very good (Kane et al., 2015).

The customer satisfaction should be such that they do not go to the competitors, but also spend more money (Jankowski, 2009); and, as the companies defend, profitability is not about capturing a customer with an offer, but winning his/her loyalty, buying more and more products and recommending them to friends, family, and acquaintances (Porter \& Kramer). The motto of business should be to conquer customers, motivate them to repeat the experience or increase their average spending. To win the loyalty of customers, companies should know their users, understand their needs and ensure satisfactory experience. To achieve it, the objective should be to use big data, analyze data and, above all enhance the relationship with the client. It can be achieved through interaction with the workers, who are the face of the organization. Also, build relationships with customers across social media platforms that have become a significant strategic marketing tool (Tuten \& Solomon, 2017).

The marketing strategy influences the behavior of the customer. Social media is, therefore, a modern technological factor that influences customer behavior. Customers want to stay connected to businesses through social media accounts such as Twitter, Facebook, and Instagram. 
Modern technology has improved connection between the business and the customers. Modern technology has also established the latest communication channels such as emails and phone calls which helps the e-customers to access the buyer easily at any time. Businesses do not have to stay open to give customer service.

The internal and external factors like cultural, social, economic and technological factors influence customer behavior; therefore, the organizations should strategize to counter these effects and embracing the modern technology should be one of them (Bahrami et al., 2012). Goh et al. (2013), in their study, claim that due to the rampant transformation in modern technology, it is necessary for all the firms and companies to change its perception/outlook towards costumers. They further explains that, today, it is easier to connect with the customer today as compared to a decade ago because of the new technology. The invention of new devices such as iPad, tablets and sophisticated laptops has empowered both the consumers as well as the suppliers to achieve their goals. This study aims to identify the impact of continual improvement of IT applications and services on e-customer behavior.

\section{Literature Review}

\section{Information Technology applications}

Information technology is defined as the use of computers, networking, and other electronic devices to create, store, and exchange all forms of electronic data. Information technology is used in business for various purposes and it has changed the customers' behavior (Bortamuly \& Goswami, 2015). One of the reasons for using modern information technology to improve the quality of work, access information, high investment, automate a business process, and increase employment opportunities (Pérez et al., 2015). The improvement in IT applications includes improved quality of work, easy access to information, high investment, automation, and employment opportunities).

\section{Improved Quality of Work}

Currently, human resources (HR) have a common goal: to seek the quality of work life for employees (Noe et al., 2017) because quality of work life is a major concern for employees. Gone are the days, when HR used to give preference to the welfare of the organization over its employees. Different studies show that offering the best environment yields benefits for employees and employers alike (Mathews \& Khann, 2016). The term work-life describes the individuals and their relation with work (Yee et al., 2009). The concept refers to tasks at work, motivation, decision-making power, job satisfaction, balance between personal and work life, and stress levels. Those are just some of the many issues that affect employees and the way they perceive their place in a company. As HRM Guide points out, for any team, maintaining a healthy and safe work environment is a way to improve motivation and productivity. Although the quality of work-life is important in every company, the reality is that not all the companies 
use the same models. Social, economic and demographic conditions can guide organizations in handling their workforce, creating benefits that fit the needs of their business.

\section{Easy Access to Information}

One of the vital factors needed in any firm is access to information. Without them, no reasonable work can be achieved. Evans (2017) argues that to achieve high standards on the customer behavior aspect, it is necessary to incorporate the modern technology. He further states all the countries who have embraced the modern information technology, 90 percent of them have witnessed boost in access to information. The access to information enables both the customer and the seller to have full information on the products or services. For any firm or business, transparency is important to be relevant to the customers, and this can only be achieved by embracing modern technology.

\section{High Investment}

According to Carey et al. (2012), investment is the act of allocating resources with the expectation of earning profit in the future. Schultz (2016) further points out that any investment involves risk factors irrespective of the nature of investment. Much like Schultz, Carey, in their research, argues that as much as investing in modern technology can be risky; the return that this advancement brings forth is worth it. This proves that by employing modern information technology, the risk of losing customers is minimized.

\section{Automation}

Parasuraman and Victor (2017), in their study on the effect of automation, defined automation as the act of undertaking a task or service by using minimal human assistance and giving more attention to technology in terms of machines systems or devices. They further state that automation, a tool of modern technology, can be the best possible way to enhance the customer behavior. According to Parasuraman and Riley (2017), automation can be classified into three groups namely: Fixed, programmable and flexible automation. Lin et al. (2010), in their study, claim that, of the 50 companies used as samples, the results showed that those who invested more on automation experienced high productivity, a higher level of efficiency, shorter workweeks for labors and reduced time.

\section{Employment opportunities}

Goldstein et al. (2018) describe employment as the act of assigning work to individuals or a group. On the other hand, McDonald (2017) describes employment as the agreement between an employer and the employee in the sense that, the employee will offer certain services and the services are mainly compensated by receiving a wage within the stipulated time. By employing modern technology, it will be easier to find employment opportunities which in turn will affect the customer behavior as more skilled labor will be employed. 


\section{E-Customer Behavior}

A marketing strategy, the study of e-customer behavior derives from the current marketing concepts that focus on customer needs (Hernández et al, 2010). The needs of the client, both current and potential, can hardly be met effectively (Achrol \& Kotler, 2012). Customer behavior refers to the set of activities carried out by a person or an organization from when they need until the moment they perform, buy and use the product later. The study of the behavior of the final customer includes the following aspects:

1. The behavior of purchase or acquisition. It covers all activities carried out to obtain a good or service, including payment thereof.

2. The behavior of final use or consumption of goods and services acquired by oneself or by third parties.

\section{Material and Methods}

\section{Instrument}

The study used qualitative method, the conceptual framework tries to explain the relationship between the variables, and a survey was conducted in order to collect the data.

\section{Conceptual Framework}

A conceptual framework of the study is presented in Figure 1 below. The framework is designed to illustrate causal relationship between study variables. The independent variable IT applications (ITA) which has been measured through the dimensions of (quality of work (QW), access to information (AI), investment (IN), automation (AU ), employment opportunities (EO), e-customer behavior (ECB)).), the dependent variable is e-customer behavior (ECB), where there are 25 items for IT applications and 10 items for e-customer behavior. To ensure that this instrument has the proper level of reliability, the test on Cronbach Alpha has been performed and is obtained with a score of 0.811 .

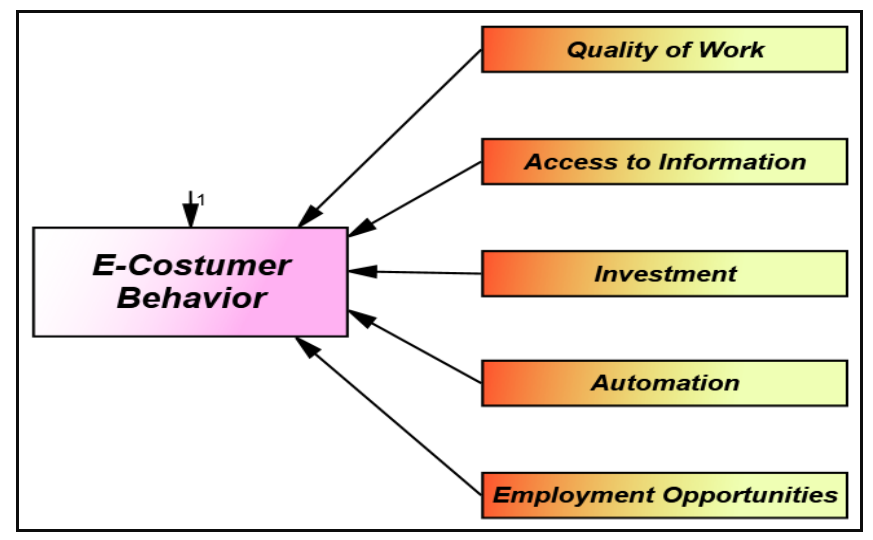

Figure 1. Conceptual Framework 


\section{Results}

\section{Factor analysis}

A proven factor analysis (CFA) was performed to measure the characterization of structures in this study (IT applications (ITA), quality of work (QW), access to information (AI), investment (IN), automation (AU), employment opportunities (EO), e-customer behavior (ECB)). First, we tested the five-dimensional model of the IT applications using the maximum probability method, Amos 21 (Hair et al., 2016). Figure 2 shows that the model corresponds to the data well because the $\mathrm{x} 2$ / df was less than 3, and all the good of the appropriate indicators was higher than 0.90 and the mean root square error (RMSEA) was (0.078) it is below the 0.08 threshold (Byrne, 2001), $\mathrm{X} 2$ / df = 2.670, $\mathrm{P}<0.01$, Comparative Index $(\mathrm{CFI})=0.953$, Good fit index $(\mathrm{GFI})=0.901$, Adjusted good fit index $($ AGFI $)=0.900$ Tucker Lewis Index $(\mathrm{TLI})=0.911$. All indicators were heavily loaded on the intended dimension (>0.40).

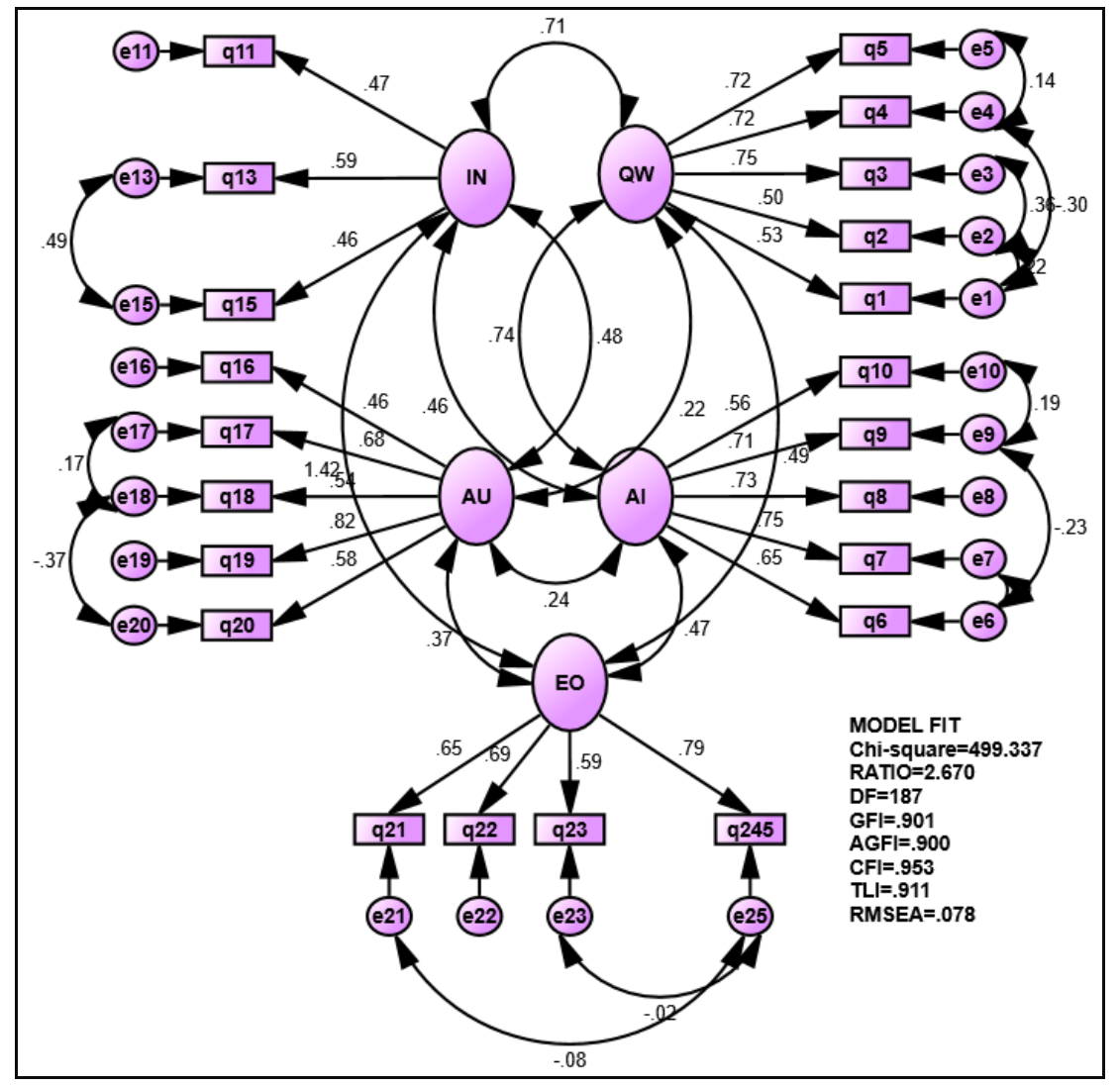

Figure 2. Factor Analysis of ITA Model

Regarding e-customer behavior Figure 3 prove that corresponds to the data well because the $\mathrm{x} 2$ / df was less than 3, and all the good of the appropriate indicators was higher than 0.90 and (RMSEA) was (0.029) it is below the 0.08 threshold, X 2 / df $=1.132, \mathrm{P}<0.01$, (CFI) $=0.995$, $(\mathrm{GFI})=0.971,(\mathrm{AGFI})=0.927(\mathrm{TLI})=0.990$. All indicators were heavily loaded on the intended dimension (>0.40). 


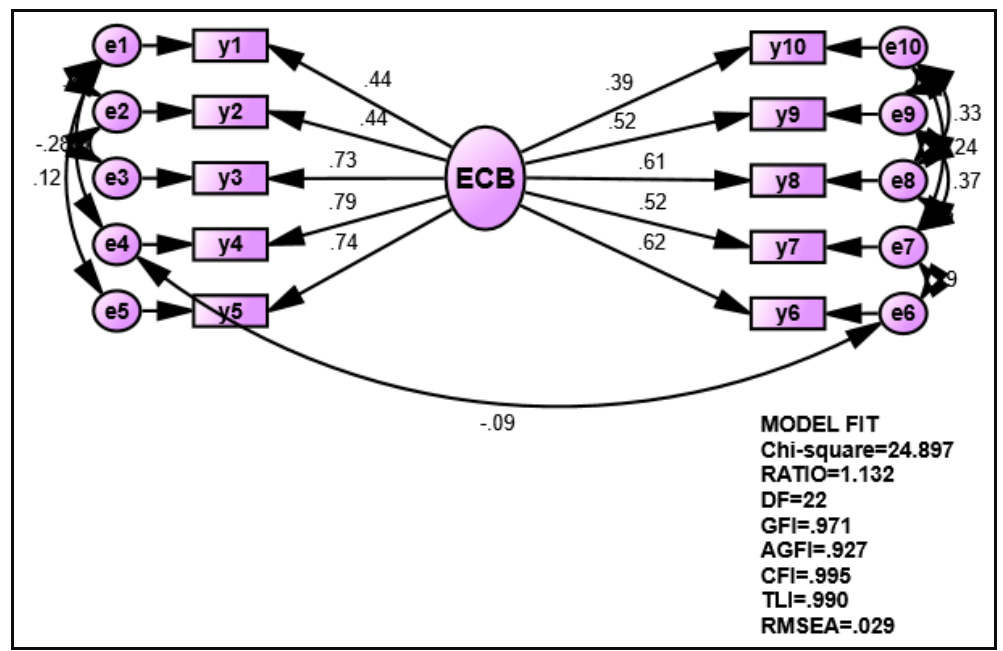

Figure 3. Factor Analysis of ECB Model

Each of the structures had a higher alpha than 0.40 indicating the recorded values were accepted (Hair et al., 2016). These results support the proper distinction of measures.

\section{Path Analysis}

Table 1 Figure 4 shows the path coefficients for each causal relationship in this study with their respective $t$ values and variants that can be explained by each endogen variable. The results of the analysis found that coefficients having $t>1.645$ were significant at five percent confidence level. Four hypotheses were supported as the $t$ value exceeds 1.96. QW has positive and significant impact on e-customer behavior $(b=0.421, \mathrm{~T}=14.459>1.96)$ which support $\mathrm{H} 1$. AI has a positive and significant impact on e-customer behavior $(b=0.393, T=14.006>1.96)$ which support H2. IN has a positive and significant impact on e-customer behavior $(b=0.421, \mathrm{~T}=$ 13.043>1.96) which support H3. X4 has a positive and significant impact on e-customer behavior $(b=0.125, \mathrm{~T}=3.859>1.96)$ which support $\mathrm{H} 4$. While one hypothesis H5 (The impact of employment opportunities on e-customer behavior) was not supported by the analysis. As expected in the study hypothesis the IT applications has a positive and significant impact on ecustomer behavior for 80 percent of the hypotheses.

Table 1. Relationship Results

\begin{tabular}{|c|c|c|c|c|}
\hline Path & Estimate & S.E. & T-Statistic & P-Statistic \\
\hline QW...> CB H1 & 0.421 & 0.017 & 14.459 & 0.000 \\
\hline AI...> CB H2 & 0.393 & 0.017 & 14.006 & 0.000 \\
\hline IN... CB H3 & 0.421 & 0.025 & 13.043 & 0.000 \\
\hline AU... CB H4 & 0.125 & 0.029 & 3.859 & 0.000 \\
\hline EO..> CB H5 & 0.048 & 0.028 & 1.531 & 0.128 \\
\hline
\end{tabular}




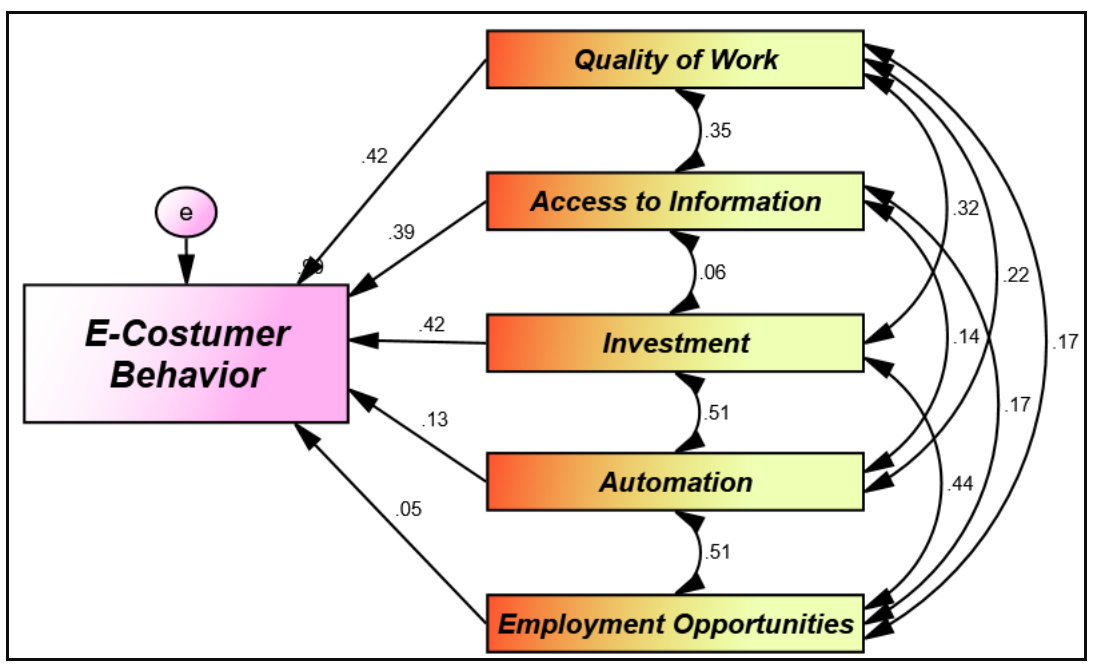

Figure 4. Path Analysis of the Model

\section{Discussion and Conclusion}

This paper aims to identify the impact of continual improvement of IT applications on ecustomer behavior on social media and the results showed positive effects on e-customer behavior.

Although some firms find the devices expensive, having them in their firm would be beneficial in understanding customer behavior. It also improves the standard of living which proves that the benefits of modern technologies are higher as compared to its shortcomings. Moreover, due to the increased competition in the marketplace globally, companies have embraced modern technology to boost studies on customer behavior. Modern technology impacts customer behavior, therefore firms should implement modern technology. Friar et al. (2014), in their research, clearly bring out that in older times customers had to go physically to the firms to buy a product, but modern technology has changed the experience and customers purchase everything online. Friar and his group explain the extent to which modern technology has made work easier. Technology has turned the world into a community as it makes the marketer reach encompassing customers of varying age groups (Chen et al., 2013).

The results showed that improved quality of work positively affects the behavior of the ecustomer. The work is done using modern information technology is of high quality and the quality of the end product is better as compared to the products produced without it. Customers prefer high-quality products (Jiang et al., 2016).

Also, easy access to information positively affects the behavior of the e-customer, that each of us has greater access to information does nothing but improve our consumption patterns, and allows greater choice and negotiation. 
High investment positively affects the behavior of e-customers; it is, therefore, clear that by employing information technology, the risk of losing customers is minimized.

Regarding automation, the results improve the importance of automation for e-customer, which results in higher productivity, a higher level of efficiency, shorter workweeks for labor and reduce time. Finally, it is important to adopt technology to create jobs for everyone. The IT applications make it easier and simpler to find employment opportunities, but it does not affect customer behavior.

According to the above, it is clear that digital transformation is not only essential for companies but also ensures their survival. The drawback of technologies is that customers' loyalty changes, so the challenge for the companies is to in love with customers. Consequently, the advantages of using information technology are:

- Saves time.

- Better deals due to the transparency in the prices of essentially homogeneous products.

- Greater differentiation of products, when companies are forced to opt for strategies, in which the price is not a valid signal at the information level to establish the quality of a product.

- Access to a greater range of products when the physical barriers of trade are broken.

\section{References}

Achrol, R. S., \& Kotler, P. (2012). Frontiers of the marketing paradigm in the third millennium. Journal of the Academy of Marketing Science, 40(1), 35-52.

Bahrami, M., Ghorbani, M., \& Arabzad, S. M.. (2012). Information technology (IT) as an improvement tool for customer relationship management (CRM). Procedia-Social and Behavioral Sciences, 41, 59-64. https://doi.org/10.1016/j.sbspro.2012.04.008

Bortamuly, A. B., \& Goswami, K. (2015). Determinants of the adoption of modern technology in the handloom industry in Assam. Technological Forecasting and Social Change, 90, 400-409.

Byrne, B. M. (2001). Structural equation modeling with AMOS, EQS, and LISREL: Comparative approaches to testing for the factorial validity of a measuring instrument. International journal of Testing, 1(1), 55-86.

Carey, J. M., \& Zilberman, D. (2012). A model of investment under uncertainty: modern irrigation technology and emerging markets in water. American Journal of Agricultural Economics, 84(1), 171-183.

Chen, I. J., \& Popovich, K. (2013). Understanding customer relationship management (CRM) People, process and technology. Business Process Management Journal, 9(5), 672-688. https://doi.org/10.1108/14637150310496758

Evans, P. B., \& Wurster, T. S. (2017). Strategy and the new economics of information. Harvard 
Business Review, September-October 1997 Issue, 71-82. Retrieved January 15, 2020, from https://hbr.org/1997/09/strategy-and-the-new-economics-of-information

Friar, J. H., \& Balachandra, R. (2014). Spotting the customer for emerging technologies. ResearchTechnology Management, 42(4), 37-43. https://doi.org/10.1080/08956308.1999.11671293

Goh, K. Y., Heng, C. S., \& Lin, Z. (2013). Social media brand community and consumer behavior: Quantifying the relative impact of user-and marketer-generated content. Information Systems Research, 24(1), 88-107.

Goldstein, B., Linder, M., Norton, L. E., \& Ruckelshaus, C. K. (1998). Enforcing fair labor standards in the modern American sweatshop: Rediscovering the statutory definition of employment. UCLA Law Review, 46, 983.

Hair Jr, J. F., Hult, G. T. M., Ringle, C., \& Sarstedt, M. (2016). A primer on partial least squares structural equation modeling (PLS-SEM). Sage publications.

Jankowski, P. (2009). Towards participatory geographic information systems for community-based environmental decision making. Journal of Environmental Management, 90(6), 1966-1971.

Jose, J. (2017). Impact of Technology on Consumer Behaviour. IRA-International Journal of Management \& Social Sciences, 6(2), 264-267.

Juaneda-Ayensa, E., Mosquera, A., \& Sierra Murillo, Y. (2016). Omnichannel customer behavior: key drivers of technology acceptance and use and their effects on purchase intention. Frontiers in Psychology, 7, 1117.

Kane, G. C., Palmer, D., Phillips, A. N., Kiron, D., \& Buckley, N. (2015). Strategy, not technology, drives digital transformation. MIT Sloan Management Review and Deloitte University Press, 14(1-25).

Lin, C. J., Yenn, T. C., \& Yang, C. W. (2010). Automation design in advanced control rooms of the modernized nuclear power plants. Safety Science, 48(1), 63-71.

Mathews, C., \& Khann, I. K. (2016). Impact of work environment on performance of employees in manufacturing sector in India: Literature review. International Journal of Science and Research, 5(4), 852-855.

McDonald, J. F. (1987). The identification of urban employment subcenters. Journal of Urban Economics, 21(2), 242-258.

Newman, A., \& Foxall, G. (2003). In-store customer behaviour in the fashion sector: some emerging methodological and theoretical directions. International Journal of Retail \& Distribution Management, 31(11), 591-600. https://doi.org/10.1108/09590550310503311

Noe, R. A., Hollenbeck, J. R., Gerhart, B., \& Wright, P. M. (2017). Human resource management: Gaining a competitive advantage. New York, NY: McGraw-Hill Education.

Parasuraman, R., \& Riley, V. (1997). Humans and automation: Use, misuse, disuse, abuse. Human Factors, 39(2), 230-253. 
Pérez-Aróstegui, M. N., Bustinza-Sánchez, F., \& Barrales-Molina, V. (2015). Exploring the relationship between information technology competence and quality management. $B R Q$ Business Research Quarterly, 18(1), 4-17.

Porter, M. E., \& Kramer, M. R. (2019). Creating shared value. In Managing Sustainable Business (pp. 323-346). Springer, Dordrecht.

Schultz, T. W. (1961). Investment in human capital. The American Economic Review, 51(1), 1-17.

Söderlund, M. (1998). Customer satisfaction and its consequences on customer behaviour revisited. The impact of different levels of satisfaction on word-of-mouth, feedback to the supplier and loyalty. International Journal of Service Industry Management, 9(2), 169-188.

Tuten, T. L., \& Solomon, M. R. (2017). Social media marketing. Sage.

Yee-Loong Chong, A., Ooi, K., Lin, B., \& Yi Tang, S. (2009). Influence of interorganizational relationships on SMEs' e-business adoption. Internet Research, 19(3), 313-331. https://doi.org/10.1108/10662240910965379

Yi, Y., \& Taeshik Gong, T. (2013). Customer value co-creation behavior: Scale development and

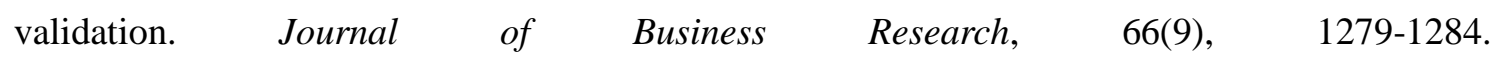
https://doi.org/10.1016/j.jbusres.2012.02.026

\section{Bibliographic information of this paper for citing:}

Meteab, A. A., Sadiq, A. S., \& Hadrawi, H. K. (2020). "Effect of continuous improvement of information technology applications on e-costumer behavior in social media." Webology, 17(1), Article 205. Available at: http://www.webology.org/2020/v17n1/a205.pdf

Copyright (C) 2020, Anaam Abdulzahra Meteab, Arcelan S. Sadiq and Hamad Karem Hadrawi. 